Kaygı, 19(1)/2020: 276-293. Araştırma Makalesi | Research Article

Makale Geliş | Received: 03.07.2019

Makale Kabul | Accepted: 04.03.2020

Yayın Tarihi | Publication Date: 25.03.2020

DOI: $10.20981 /$ kaygi. 705300

Melina DUARTE

UiT The Arctic University of Norway Department of Philosophy

ORCID: 0000-0003-2099-7349

melina.duarte@uit.no

\title{
EU-Turkey Refugee Deal: Buck-Passing and Bargaining on Human Lives at Risk?
}

\begin{abstract}
Since the early stages, the EU-Turkey Refugee Deal has generated several controversies concerning its legal and moral standing. In the first section of this paper, for important informative purposes, I will briefly discuss several points related to how the legality of the deal could be contested. In the second section, I will turn my attention to a more detailed examination of whether the deal could be considered immoral with regard to two morally condemned practices, namely: buck-passing, or evasion of responsibility, and bargaining on human lives at risk. In the final section, I will attempt to outline guiding principles for a hypothetical deal that would be more responsive to the principles underpinning the Refugee Convention than the morally condemnable principles in the actual deal based on those two grounds discussed here.
\end{abstract}

Keywords: Refugee Crisis, Relocation, Human Rights, International Relations, State's Responsibilities.

\section{AB-Türkiye Sığınmacı Anlaşması: Tehlike Altındaki İnsan Hayatlarına Dair Sorumluluğu Başkasına Yükleme ve Pazarlık mı?}

$\ddot{O} z$

AB- Türkiye Sığınmacı Anlaşması, başlangıcından beri, yasal ve ahlaki bakımdan çeşitli ihtilaflara yol açtı. Bu makalenin birinci bölümünde, önemli bilgiler vermek amacıyla, anlaşmanın meşruiyetine/hukuki geçerliliğine nasıl itiraz edilebilir olduğuna ilişkin kısaca bazı noktaları tartışacağım. İkinci bölümde, dikkatimi anlaşmanın ahlaken kınanan iki uygulama ile ilgili olarak ahlak-dışı sayılıp sayılamayacağı üzerine daha detaylı bir soruşturmaya çevireceğim: Yaşamları tehlike altındaki insanlar konusunda sorumluluğu başkasına yükleme ya da sorumluluktan kaçma ve pazarlık yapma. Son bölümde, olası bir anlaşmanın yönlendirici ilkelerinin ana hatlarını çizmeye çalışacağım. Bu yönlendirci ilkeler, sığınmacı anlaşmasını temellendirmede, mevcut anlaşmanın dayandığı burada tartışılan ahlaken kınanabilir iki temel ilkeye kıyasla daha etkili olacaktır.

Anahtar Kelimeler: Sığınmacı Krizi; Yer Değiştirme; İnsan Hakları; Uluslararası İlişkiler; Devlet Sorumlulukları. 


\section{Introduction}

On 4 April 2016, the EU-Turkey Refugee Deal began being put into practice in an attempt to respond to challenges imposed by the current migration crisis. On the first day of operation, 202 asylum seekers were sent back to Turkey from Greece and many more followed after that. ${ }^{1}$ The deal aims to hamper smugglers and ultimately stop irregular immigration from Turkey to the EU. In order to achieve this goal, the deal endorsed during the March 18 Summit outlines the following measures ${ }^{2}$ : (1) all irregular immigrants arriving in Greece after March 20 will be returned to Turkey with the costs of this operation being covered by the EU; (2) for every Syrian refugee returned to Turkey from Greece, another Syrian refugee will be resettled in the EU in the territory of member states that voluntarily agree to receive them; (3) Turkey will be responsible for blocking illegal migration routes from Turkey to the EU; (4) the EU will start the resettlement of refuges from Turkey only after irregular crossings have stopped or at least "substantially and sustainably reduced"; (5) once Turkey has ensured its part of the deal, the EU will review the lifting of visa requirements for Turkish citizens; (6) the EU will immediately disburse three billion euros to the Facility for Refugees in Turkey and an additional three billion euros by the end of 2018; (7) the Customs Union between the EU and Turkey will be upgraded; (8) the EU will reconfirm its commitment to "re-energise the accession process" of Turkey into the EU and agreed to open Chapter 33 of the Community Acquis ${ }^{3}$ (total body of EU law) concerning financial and budgetary provisions.

Since the early stages, the deal has generated several controversies concerning its legal and moral standing. In the first section of this paper, for important informative purposes, I will briefly discuss several points related to how the legality of the deal could be contested. In the second section, I will turn my attention to a more detailed

\footnotetext{
${ }^{1}$ See: http://www.theguardian.com/world/2016/apr/05/greece-deport-migrants-turkey-united-nationseuropean-union

${ }^{2}$ See: http://www.consilium.europa.eu/en/press/press-releases/2016/03/18-eu-turkey-statement/

${ }^{3}$ See: http://ec.europa.eu/enlargement/policy/conditions-membership/chapters-of-the-

acquis/index_en.htm
} 
examination of whether the deal could be considered immoral with regard to two morally condemned practices, namely: buck-passing, or evasion of responsibility, and bargaining on human lives at risk. In the final section, I will attempt to outline guiding principles for a hypothetical deal that would be more responsive to the principles underpinning the Refugee Convention than the morally condemnable principles in the actual deal based on those two grounds discussed here.

\section{Does the EU-Turkey Deal violate International Law?}

Legally, both the EU and Turkey might be infringing international law given that some aspects of the deal possibly violate the 1951 Refugee Convention and the 1967 Protocol, to which all EU state members and Turkey are signatories. The Convention is underpinned by three fundamental principles ${ }^{4}$ : (a) non-discrimination, (b) nonpenalization, and (c) non-refoulement.

Concerning non-discrimination, the fact that the EU-Turkey Refugee Deal refers mainly to Syrian refugees might violate the non-discrimination criteria regarding discrimination based on country of origin. Turkey, however, retains a geographical limitation to its ratification of the convention, allowing the country to recognize and grant refugee status only to those fleeing from Europe. ${ }^{5}$ Thus, if the deal does violate the non-discriminatory principle, only the EU would be legally subjected to the Convention and Turkey would so far appear to be immune from it. (b) The principle of non-penalization requires host countries not to charge refugees with immigration or criminal offences or to detain them arbitrarily merely on the grounds that they are seeking asylum. According to this principle, even if there were no formal charges for violating immigration laws on the part of the states, the mere treatment of asylum seekers as criminals might already entail a violation of the refugees' rights. If we think of how the borders are being managed now in Turkey and Greece, how militarized they are and how people have been forced to the camps escorted by armed personnel, we

\footnotetext{
${ }^{4}$ See: http://www.unhcr.org/3b66c2aa10.html

${ }^{5}$ See: https://www.hrw.org/reports/2000/turkey2/Turk009-10.htm\#P469_114196,p.3
} 
could believe that refugees are, in a way, being penalized, i.e. treated as criminals, simply for seeking asylum. If these allegations are proven, both the EU and Turkey could be charged for violating this principle. (c) The third principle is non-refoulement, meaning that "no one shall expel or return ("refouler") a refugee against his or her will, in any matter whatsoever, to a territory where he or she fears threats to life or freedom." This principle is so fundamental that it requires full compliance and no reservations are admitted. The sad news is that both the EU and Turkey seem to be violating this fundamental principle. According to the Director of the UNHCR's Europe bureau, Vincent Cochetel, among the 202 immigrants that were sent back to Turkey on April 4, thirteen (Afghans and Congolese) were not allowed to register their asylum claims due to the chaos in Greece and yet were returned to Turkey as irregular immigrants. To determine who is an irregular immigrant, asylum seekers must have the chance to register their claims and have their applications properly assessed, which possibly failed to happen in this case. Another possible violation of this principle by the EU relates to how safe for refugees Turkey really is when it comes to threats to life or freedom. John Dalhuisen from Amnesty International claims that enough evidence exists to believe that Turkey has been sending refugees back to Syria since mid-January and has already returned several thousand including unaccompanied children and pregnant women. ${ }^{6}$ Thus, even if Turkey could be considered a safe country for refugees regarding in loco threats to life, which is a contested point, the fact that Turkey seems to be violating the non-refoulement principle by sending refugees back to the country they fled from during an ongoing war, might show that the EU violates this principle when returning refugees from Greece to Turkey as well. The status of Turkey being a safe place for refugees is contested on multiple grounds, prominently highlighted by the Syrian Observatory for Human Rights who have documented a series of abuses from the

\footnotetext{
${ }^{6}$ See: https://www.amnesty.org/en/press-releases/2016/04/turkey-illegal-mass-returns-of-syrian-refugeesexpose-fatal-flaws-in-eu-turkey-deal/
} 
Turkish authorities at the Syrian border including the recent shoot deaths of sixteen refugees. Three of them were children. ${ }^{7}$

\section{Is the EU-Turkey Deal morally condemnable?}

Is the Deal a political act of buck-passing?

Buck-passing is generally defined as "the practice of shifting the responsibility for something to someone else". ${ }^{8}$ When I was a child, my mother said that she wanted to see my and my sister's bed made soon after we got up. Based on my mother's demand, I quickly realized that the task could be accomplished without me actually having to make my own bed, but by persuading my little sister to do it for me. We played "house owner" and "housekeeper". She enjoyed playing, as did I, perhaps even more than her for secret reasons. Everything looked good on the surface: beds made and kids happy. The fact that the formulation of mother's demand was open allowed me to twist it by transferring my responsibility for doing something to somebody else without being directly accountable for the means used to accomplish the task. My mother did see the beds made soon after we got up after all and that was literally what she asked for. It is, however, needless to say that my mother's intention was to have us both make our own beds. In a deep sense, I knew I was construing the rule in my favor when passing the buck to my sister, trying to be smart and act in my best interest. My mother could not blame me directly because she felt that she should have set the conditions by which the task should be accomplished. Instead, she came up with a new demand that would make my misleading interpretation impossible. She said that she wanted to see us both making our own beds soon after we got up. Had she not done that, I would not have learned that evading responsibility was wrong and that it could compromise my relationship of trust with my sister. If my sister had found out by herself that she was being misguided by me and I had insisted there was nothing wrong with my behavior by rationalizing it though a biased interpretation of the rule, she would have enough

\footnotetext{
${ }^{7}$ See: http://www.theguardian.com/commentisfree/2016/apr/01/turkey-safe-haven-refugees-shootsborder-illegal-deportations-syrians

${ }^{8}$ See definition: http://www.oxforddictionaries.com/definition/english/buck-passing
} 
reasons not to play with me anymore. She was being deceived. Buck-passing is indeed a common practice that happens even among children, but this does not make it less damaging for the flourishing of any kind of relationship. This example might appear naïve and applicable only the personal sphere, but it is not far from buck-passing in international politics where much more is at the stake.

In international politics, the term "buck-passing" has been used to describe a pattern of action in which one or more states strategically transfer the burden of dealing with a determined problem or challenge to another state or group of states, hoping to benefit from it such that they bear no or minimal costs. Stephen M. Gardiner (2011: 302-305), a philosopher working at the University of Washington, uses the term to understand our generation's reluctance to tackle effectively the problems of climate change, leaving the issue for future generations to resolve. John J. Mearsheimer (2001), a neorealist political scientist, used the concept to describe situations in history in which drawbacks were purposely used by great powers to achieve hegemony. From these descriptions, he was able to extract and systematize some of the common and complex dynamics among buck-passers, buck-catchers, and the target. Among other historical examples, he identifies Britain's minimal efforts in sending troops to war in the beginning of the WWI as an act of buck passing, leaving the burden of fighting the German Army to its allies, France and Russia. According to him, the goal was to get on board with troops in the final battles and, emerging as the strongest power, to set the terms of peace in their favor. A similar situation occurred during WWII when the US was said to benefit from buck-passing. Despite having formally entered the war in 1941, the US waited until the last half of 1944 to send troops into battle, a few months before the war ended, possibly shifting the responsibility of fighting to the Soviet Union. For this, the US were accused by Stalin of letting others bleed in order to emerge as the dominant power after the war. Since states are not as naïve as a little sister, they are, of course, aware of this practice and they do not want to be the buck-catchers themselves. The buck then passes from one to the other. In order to make it stop in someone else's hand, states have to use sophisticated methods of political negotiation. Mearsheirmer 
says, "great powers can mobilize additional resources of their own to make buckpassing work." This is, however, not a genuine share of responsibility, but an attempt to deceit other states. Being an attempt to get a "free" or a "cheap ride" by relying on others bearing most of the costs, buck-passing in politics can be very harmful when it comes to establishing successful alliances and genuine forms of international cooperation. If healthy international relations cannot be established because countries cannot be trusted, we should have no hope to tackle many global challenges that requires conjoint action such as international migration, poverty, climate change.

Now that we know enough about the concept of "buck-passing" and understand the basics on why it is harmful to the good functioning of international relations, I invite you to reflect with me on whether the EU-Turkey Deal can be considered an act of buck-passing and immoral on this ground. A leaked transcription of confidential negotiations ${ }^{9}$ between Recep Tayipp Erdogan, president of Turkey, Jean-Claude Juncker, president of the European Commission, and Donald Tusk, president of the European Council, can help us in this endeavor. In this conversation, Erdogan criticizes the EU for not wanting Turkey as a member and delaying the decision by failing to open the remaining chapters of the Community Acquis. Erdogan says: "You just want us to keep all the refugees." Tusk then replies: "I am not trying to cheat, but you have to recognize that the EU is complicated. We need all 28 [member states] on board." Based on what we know, do we have reasons to think that Erdogan is right when accusing the EU of evading responsibility when it comes to taking care of the refugees? Let us not consider the accession questions for now since this will be discussed in the next section, but rather concentrate on the refugee question. Is it possible that the EU is passing the buck to Turkey in order to solve the matter?

Usually migration flows are affected by geography, which means that those countries closest to the disturbed zones will end up by receiving the largest number of refugees and suffering the biggest burden. This is the case in Lebanon now where a very high ratio of natives per refugee exists and difficulties to provide for its their citizens

\footnotetext{
${ }^{9}$ http://www.euro2day.gr/news/economy/article/1397081/hontro-paihnidi-sth-plath-ths-elladas.html
} 
persists as a result. Correcting for these discrepancies is imperative to alleviate the pressure on the most affected countries and to ensure that proper assistance is provided for those refugees in need. If a country fails to provide the minimal to its own citizens, it is hard to expect that the basic needs of the refugees are going to be met in these places. This is, however, not an excuse for low-income and developing countries not to take in any refugees, but just a note that these economic and political differences should be taken into account when managing the resettlements. ${ }^{10}$ The chart below compares the refugee population in Turkey to those EU member states most affected due to their geographical position. It shows that Turkey has a much larger refugee population than the EU members states from where refugees are supposed to be relocated.

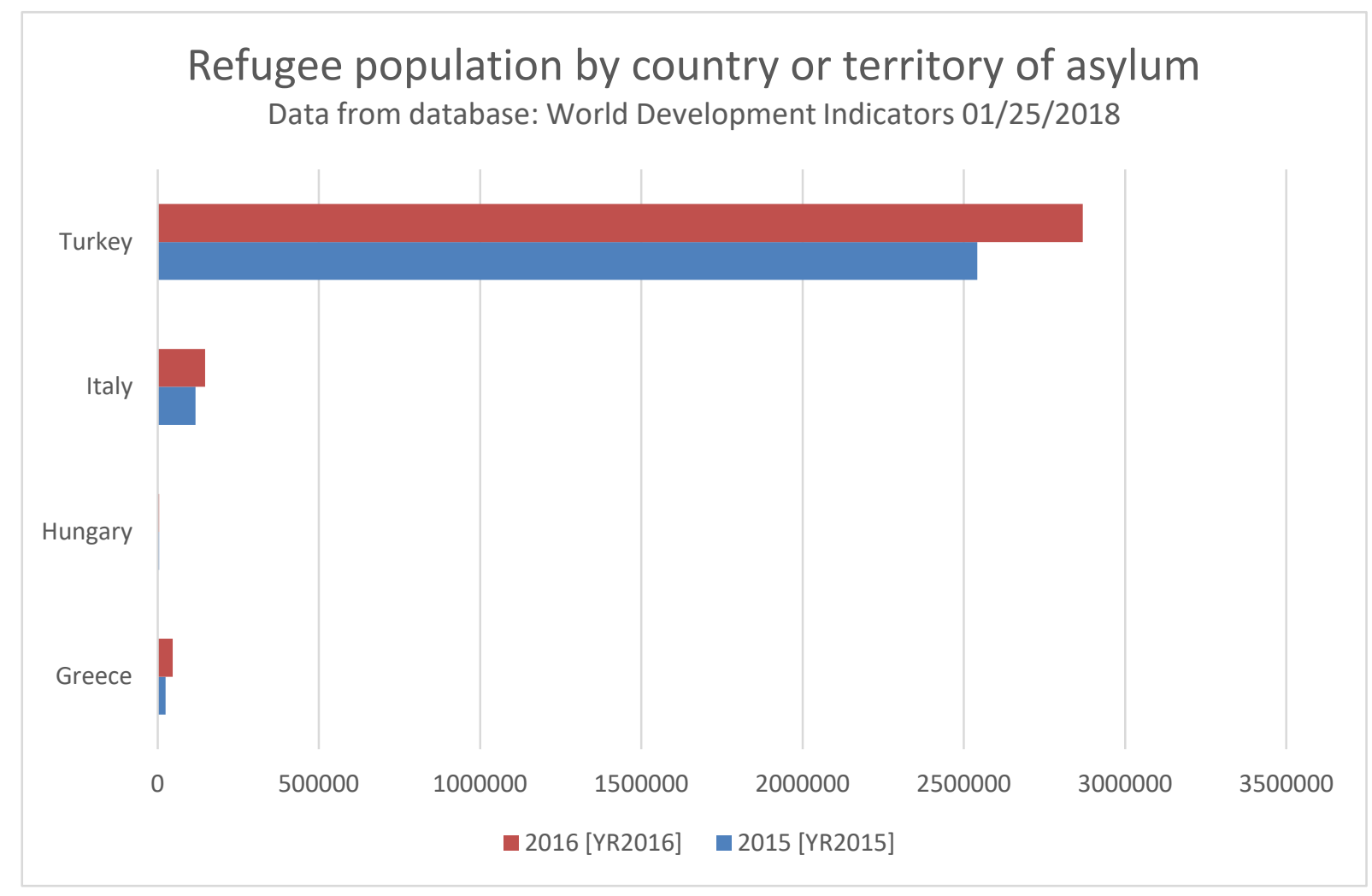

\footnotetext{
${ }^{10}$ The EU Relocation Scheme (2015-2017) did take these differences into account in order to calculate a fair distribution system for the member states. Despite the mathematical problems in terms of calculating the distribution, and despite its actual failure in practice, the idea behind it is sound. See: EU Fact Sheet, 22 September 2015. Available at http://europa.eu/rapid/press-release_MEMO-15-5698_en.htm
} 
In light of this chart, we have to ask: what is the point of sending refugees back to a country that is clearly already overstretched and that, despite being a developing country, has absorbed more refugees than countries where refugees are supposed to be relocated? In this respect, the deal seems not to be in favor of the refugees, but in favor of the EU. Not only does Turkey look like a buck-catcher, but so do Greece, Italy, and Hungary as they serve as a wall to migrants that would otherwise move to other places in Europe. The deal does not correct the influxes occurring due to geographical proximity of the disturbed zones, but actually does the opposite by sending migrants back to these zones. The official goal of the deal is not, however, to reduce the number of refugees coming to Europe, but to tackle the actions of smugglers and to contain irregular immigration from Turkey. As we saw in deal's list of measures, the EU is also assuming some responsibilities. The EU will cover the costs of these return operations and will disburse a total of six billion euros to Turkey by the end of 2018 to maintain the camps and facilities hosting the refugees there. If the goal is to block the smugglers' route, maybe the EU should make a similar deal with Libya in the future to stop the irregular immigration into Italy. President Erdogan says, in the leaked conversation cited above, that this amount of money is an insult, since the EU, in times of crises, has disbursed more than 400 billion euros to Greece. Tusk replies that the bailout was not only about Greece, but about the Euro zone. Erdogan interrupts by saying “....and about the Schengen, again a European project." But there is another measure in the deal that suggests a shared responsibility from the EU side, namely the 1:1 measure which stipulates that for each irregular migrant sent back from Greece to Turkey, another refugee settled in Turkey will be resettled in the EU. The fishy part of this measure is that it is supposed to be put into practice only after Turkey has honored its part of the deal and the influx of irregular immigrants from Turkey is stopped or at least, how they put it in the official document, “"substantially and sustainably reduced”. This might be an unrealistic expectation or, at least, an open rule that would always allow the EU to evade its part of the deal by saying that the reduction or irregular immigration from Turkey was not substantially and sustainably reduced — whatever the numbers might be. The EU resettlements were also subjected to the voluntary will of the member states to 
host these refugees and, in practice, only a small part of what was planned were actually resettled within the EU. Some member states are closing their borders in an attempt to regain sovereignty over border control and are increasingly distancing themselves from EU directives on the matter. Examples of this include the UK, Denmark, Hungary, and Poland. Thus, if the implementation of the 1:1 measure will be conditional on ending or substantially reducing irregular migration and depending on the willingness of the individual member states to take refugees in, the likelihood of its success might be very small. Observing the non-refoulement principle would also be of no help, since a state abiding by the convention does not have an obligation to resettle refugees that are already in a safe zone. Despite warnings by the UN and other international organizations, for all the effects, Turkey is considered a safe zone for the refugees now. Despite disagreements on the amount, the initial three billion euros is the only part of the deal that is assured. Recalling Measheirmer's words about great powers mobilizing additional resources to make the buck-passing work, this financial help does indeed seem suspicious. Will Mearsheirmer's theory of offensive realism one day be used to analyze and describe this fact as Europe's buck-passing in an attempt to achieve hegemony? For this we will have to wait for the history to be written.

\section{Bargaining on Human Lives at Risk?}

Perhaps we should not be under the illusion that EU states and Turkey are acting in best interest of refugees. The EU wants to stop the uncontrolled inflow of irregular immigrants coming through Turkey and Turkey wants to become a member of EU, but the negotiations had been frozen for years. In this context, the current migration crisis seems to have appeared to Turkey as an opportunity to reopen the negotiations. At the same time, Turkey's willingness to be part of the EU also seems to have appeared as an opportunity for the EU to make them catch the heavy buck of the migration crisis. The evidence points in this direction: the leaked transcriptions mentioned in the previous section of this paper starts with President Erdogan acknowledging progress made during the G20 Summit (November 2015) on migration and counter-terrorism. He said, "A lot 
of good progress since on migration and counter-terrorism, etc. But still the EU hasn't open a single chapter. Not 15, 17, 23, 24, 25 or 31 . We are lagging behind. What can be done?". Juncker then replied that "all these elements - migration, accession, visas, etc. - must be seen as a package". We see here that it is precisely this clear linkage between migration (here meaning the migration crisis), accession, and visas that reveals that these elements might have been exchanged in a dubious way. To use the vulnerable refugees in order to advance diverse national political agendas can be a case of bargaining on human lives at risk. After that, the conversation diverged to disputes about money. Erdogan said Turkey did not need any money from the EU and that they had already spent around eight billion euros on refugees by the then. This was to clarify that Turkey would not catch the buck only for money, let alone for a small amount. Tusk replied by explaining the difficult situation being faced by the EU, saying: "Some of the member states were ready to close down Schengen, especially after Paris. If we cannot show that we have a deal now, things can turn dramatic." And, of course, if the Schengen was closed down, the visa-free area for Turkish people would also be closed down. Then, Erdogan tried to dramatize the conversation by asking: "So how will you deal with refugees if you don't get a deal? Kill the refugees?" Tusk said that if they fail to strike a deal, the EU can also make itself less attractive to refugees. (This is actually what Denmark is already doing in various ways.) But before Tusk could reverse the advantage position in the negotiation, Erdogan came forth with a threat: "The EU will be confronted with more than a dead boy on the shores of Turkey. There will be 10.000 or 15.000. How will you deal with that?"

Although disturbing, there is something fascinating about this leaked confidential conversation: it provides us with a naked view of politics where we can really see what is at stake without the cover of a politically correct discourse. It seems that there is no doubt that human lives at risk are the object of political bargaining. For some, simply seeing such negotiations as bargaining on human lives is already enough to make it morally condemnable, especially when these lives are at risk. For others, however, states are somehow cornered into this practice as they must represent their citizens and 
protect their interests. The consequences are unavoidable even if they are regrettable. Two factors appear to be affecting these different positions: (1) one related to the conception of politics and (2) another related to how duties and responsibilities towards the others are viewed. (1) While according to the former view, politics might be understood as an instrument of morality, for the latter politics is different from morality with politics not necessarily being moral - especially when this entails sacrificing the their self-interest and well-being and that of their kin. (2) Whereas the former extends the duties and responsibilities of the states to assist human beings regardless of their country of origin, the latter conceives states as having a priority of duties and responsibilities towards their own people. But is this strategy of bargaining on human lives at risk really smart in terms of politics? We have to keep in mind that there is a reason why we have moral principles to guide our actions. This is not just an invention of good and benevolent souls. The reason is to make politics possible and civilized among several actors. If politics were deprived of any morality, understanding it as a basic code of conduct, there would be no foundation for treaties, conventions, or even for human rights. International relations would be condemned to chaos.

Bargaining on human lives at risk is morally condemnable because it crosses the threshold of what is being traded. Human lives ca not simply be traded because this constitutes a failure to consider them as equals and worthy of dignity and respect. ${ }^{11}$ Slavery is historically condemned for this reason and the marketing of refugees might fall into the same category when failing to take into account not only the welfare of the refugees, but their agency as well. ${ }^{12}$ Thus, even if we were to assume that states must prioritize the wellbeing of their own citizens (which is contested by many cosmopolitans), marketing human lives should not be part of the equation. In this respect, the EU-Turkey Refugee Deal seems to violate this criterion of universal moral equality when treating the refugees as objects of a deal made to advance independent national political agendas. In this context, refugees are destitute of their most basic right

\footnotetext{
${ }^{11}$ For a detailed account on the moral limits of trade, see: Sandel 2013.

${ }^{12}$ For clarifications on this differentiation between welfare interests and agency, see Sen 1987.
} 
when their status as human beings of equal standing is undermined for the gain of other parties. They are severely downgraded, humiliated, and subordinated to an unaccountable power that exploits and takes advantage of their situation of vulnerability. These extremely bad outcomes for the refugees are reduced to "externalities" or "collateral damage" when they are more than that. The political philosopher, Debra Satz (2012, Ch.4) defends an account of trade in which defining what should be part of the equation should pass the scrutiny of the quality of outcomes that are produced not only for the individual themselves (including third parties) but also to the society as a whole. According to her, a deal that exploits vulnerability supports extremely harmful and unequal social relationships, threatening not only individual rights but also the legitimacy of democratic governance. These reflections serve as a warning when showing that our attempts to be smart and act only according to our own interests, at the individual and state level, might actually be driving us farther away from our goals of living in a free and democratic society.

\section{Conclusion}

In this paper, I tried to show that the EU-Turkey Refugee Deal can be contested on legal and, especially, moral grounds. The deal and its implementation do seem to be violating some of the fundamental principles underpinning the Refugee Convention and Protocol and do appear to fall into the morally condemned cases of buck-passing and bargaining on human lives at risk. The question now is whether, realistically, we can expect to set up a deal that would not be condemned on these grounds. A realistic account should be sensitive to the fact that states would act in their best interest and that international relations are unstable and, to some extent, unpredictable. It is in best interest of states to manage the migration crisis in an effective way for them not to be overburden by the uncontrolled influx of migrants into their territories. It is also in their best interest to protect their citizens against the instability that might disrupt their territories and displace their own citizens in the future (e.g., today Europe is facing immigration pressures, but not so long ago it experienced significant emigration as 
people fled war and poverty). For this relationship to work every state must become a buck-catcher. Divided, the buck will be much lighter and states can be ensured they are not going to be overwhelmed or threatened by it. As some states are not willing to comply with it in a voluntary manner, and the solution to such a global issue depends on a global undertaking, their discretionary rights over admissions and settlements of refugees should be revoked. There is nothing illegitimate about this if we already abide by laws at the domestic level. For example, say that I enjoy car racing and would prefer to drive over the speed limit. The reason why I cannot do that, and will be punished if I do, is not only because I could die or kill someone, but because if everyone else could do the same there would be a chaos and the roads would be even more inhospitable for drivers, pedestrians, and everybody else that uses this public space. As citizens and residents, we need to abide by some laws and compromise our individual wishes and desires when living in societies because this is the way our common existence can flourish. This compliance to the law is, in practice, not voluntary in the sense that we were not asked for our consent to become subjects of the law. It is at least puzzling that states can do whatever they want at the international level, given that their actions affect other states and peoples.

In a voluntary scheme of admissions of refugees, we can show at least two inefficient scenarios: (1) nobody wants to volunteer because the number of states that will not admit refugees is too large or growing and they are afraid of being left with more refugees than they think they can handle; (2) the majority of countries agrees to volunteer, but those who don't agree are indirectly rewarded for not spending resources on it and are, as a result, placed in a situation of advantage in relation to the others. Accounting for this and given that the migration crisis is affecting everybody in different degrees, a principle of justice could justify the end of voluntary participation in admission schemes. Admissions and settlements would then be better managed at the global level to which the states would be subjected to decisions take at the global level in a similar way that we, as individuals, are subjected to state laws today. If the state's authority towards us is legitimate, it becomes difficult to argue that a global order would 
not be able to justify the same relationship towards states. This is because the arguments holding it back are based on an old conception of state sovereignty that no longer represents our current reality and cannot respond to our current global challenges. Going from voluntary to compulsory admissions and settlements is a change in the rule that would disable opportunistic states to evade their responsibilities on global issues. Of course, this change might not happen without struggle. If compulsory schemes of admission/relocation would avoid buck-passing, it would not yet avoid negative bargaining on human lives. To avoid bargaining about people's lives at risk, the number of admissions and settlements should be regulated by an objective formula accounting, for example, for the size of the territory, population and GDP, as seen in the EU Relocation Scheme (2015-2017) but with a larger, global scope. Although the EU Relocation Scheme failed in terms of the number of relocations executed, it did serve to create the possibility for a change in the default structures currently ruling border control-- from individual states to a common, in this case supranational, structure. Members states that refused to take part in the scheme are now being referred to the EU court of justice for "non-compliance with their legal obligations on relocation" ". The outcome of the lawsuit is still uncertain, but their replies provided in a former stage of the infringement procedure were considered unsatisfactory. Whatever happens, this is a clear sign that the era of state sovereignty over border control is already withering in practice. If this idea is embraced, we will need to work out ways of perfecting it. What cannot be perfected is a system that long ago became dammed to fail. The migration crisis is a global issue that cannot be treated within state borders by state agents in a world of increasing human mobility across borders. This is a retrograde way of understanding the current changes that fail to take into account that the influx of migrants will perhaps never stop. If not wars in Syria, Afghanistan, Iraq, other wars and conflicts may come. Also, other reasons press on international human mobility such as changes in the environment, globalization, family reunion, escape from poverty, and the hunt for opportunities. Thus, if we want to be smart and help ourselves, let us do in it a

\footnotetext{
${ }^{13}$ See: EU Press releases 7 December 2017. Available at http://europa.eu/rapid/press-release_IP-175002_en.htm
} 
proper way and think of better solutions. We cannot help ourselves without helping others.

\section{Acknowledgments}

This paper was developed as part of the project Exclusive Citizenship and Contemporary Theories of Transnational Justice, led by M. Turowski and A. Chmielewski. The project involved the cooperation of the University of Wroclaw (Poland), Uludag University (Turkey), and the research group Pluralism, Democracy, and Justice (PDJ), UiT The Arctic University of Norway. I am grateful for the hospitality received in Poland and Turkey during my research visits and for the funding received from these three institutions. I am also grateful to A. Vitikainen, N. Holtug, Y. Yusukeda, M. Lemberg, T. I. Hanstad for their valuable and poignant comments on a previous version of this paper and to K. Mällberg for lending me some books on buckpassing. 


\section{REFERENCES}

Aamann, Preben. "EU-Turkey statement, 18 March 2016", European Council, Foreign Affairs \& International Relations, Press release 144/16, March 18, 2016.

Amnesty International. Turkey: Illegal mass returns of Syrian refugees expose fatal flaws in EU-Turkey deal. April 1, 2016.

European Neighbourhood Policy and Enlargement Negotiations. Chapters of the Aquis, 2014-2015.

EU Press releases, 7 December 2017. Available at http://europa.eu/rapid/pressrelease_IP-17-5002_en.htm

EU Fact Sheet, 22 September 2015. Available at http://europa.eu/rapid/pressrelease_MEMO-15-5698_en.htm

Gardiner, Stephen M. A Perfect Moral Storm: The Ethical Tragedy of Climate Change. Oxford University Press, 2013.

Human Rights Watch. Turkey: Human Rights and the European Union Accession Partnership. Protecting the Refugees. September 2000.

Kingsley, Patrick. "Turkey is no 'safe haven' for refugees - it shoots them at the border." The Guardian, April 1, 2016.

Kingsley, Patrick. "Greece may have deported asylum seekers by mistake, says UN.” The Guardian, April 5, 2016.

Mearsheimer, John J., The Tragedy of Great Power Politics. W.W. Norton \& Company, 2014.

Oxford dictionaries. Oxford University Press, 2016.

Papamiltiadou, Angeliki, Thick game on the back of Greece, Euro2day, February 08, 2016.

Sandel, Michael. What Money Can't Buy: The Limits of Markets. Farrar, Strauss and Giroux, 2013.

Satz, Debra. Why Some Things Should Not Be for Sale: The Moral Limits of Markets. Oxford University Press. 2012.

Sen, Amartya, On Ethics and Economics, Oxford, Basil Blackwell, 1987.

UNHCR. 1951 Convention Relating to the Status of Refugees and 1967 Protocol.

World Bank. World Development Indicators, Refugee Population by country or territory of Asylum. Database 2010-2014. 